\title{
Evidence for maternal regulation of early conceptus growth and development in beef cattle*
}

\author{
J. E. Garrett $\dagger$, R. D. Geisert $\dagger$, M. T. Zavy§ and G. L. Morgan $\ddagger$ \\ $\dagger$ Animal Science Department and $\ddagger$ Department of Veterinary Medicine and Surgery, \\ Oklahoma State University, Stillwater, OK 74078, U.S.A.; and $\S U$ S Department of Agriculture, \\ ARS, El Reno, OK 73036, U.S.A.
}

\begin{abstract}
Summary. Fifty-one cyclic beef cows were mated with fertile bulls. At $36 \mathrm{~h}$ after the start of oestrus, cows were assigned to receive sesame oil (controls) or progesterone $(100 \mathrm{mg}$ ) on Days 1, 2, 3 and 4 of pregnancy. Peripheral plasma concentration of progesterone was measured until slaughter on Days 5 or 14. Cows were randomly assigned to be slaughtered on Days 5 or 14 or remain intact and palpated per rectum on Day $\mathbf{4 0}$ to verify pregnancy. Uteri on Days 5 and 14 were flushed for recovery of luminal protein and conceptus tissue. Conceptus and endometrial tissues were cultured with $\left[{ }^{3} \mathrm{H}\right]$ leucine and submitted to two-dimensional-PAGE and fluorography.

Administration of progesterone increased peripheral plasma progesterone concentration on Day 2-5. Conceptuses recovered from progesterone-treated cows on Day 14 were advanced in development compared to conceptuses from control cows. Conceptuses recovered from progesterone-treated cows were viable as polypeptides associated with maintenance of pregnancy in cattle were synthesized and released at an earlier time and pregnancy was maintained beyond Day 40 . Early progesterone stimulation altered the synthesis and release of polypeptides from endometrial explant cultures on Day 5. Results indicate a role of progesterone in the maternal regulation of conceptus growth and development in early pregnancy of cattle.
\end{abstract}

Keywords: cattle; progesterone; uterus; pregnancy; embryo

\section{Introduction}

Administration of exogenous progesterone early in the oestrous cycle shortens the interoestrous interval in the ewe (Woody et al., 1967; Ottobre et al., 1980; Lawson \& Cahill, 1983) and cow (Woody et al., 1967; Woody \& Ginther, 1968; Harms \& Malven, 1969; Ginther, 1970; Battista et al., 1984). Shortening of the oestrous cycle length is proposed to result from an earlier release of prostaglandin (PG) F-2 $\alpha$ from the uterine endometrium (Ottobre et al., 1980; Garrett et al., 1987). Therefore, it has been suggested that exposure to exogenous progesterone early in the oestrous cycle advances uterine secretory development.

Embryo transfer studies have emphasized the need for close synchrony ( $\pm 24 \mathrm{~h}$ ) between the conceptus and recipient (Rowson et al., 1969; Betteridge et al., 1980). Close synchrony is essential as the conceptus and maternal system form a complex communication network involving secretions from the conceptus as well as from the uterine endometium. These secretions stimulate and mediate changes throughout the early pregnancy period and have been implicated in maintaining pregnancy and facilitating conceptus growth and development. Ovarian steroids, especially

*Reprint requests to Professor R. D. Geisert. 
progesterone, play an important role in regulating changes in the uterine environment conducive to attachment and survival of the conceptus.

Previous studies in the ewe have shown that progesterone administration during the first few days of the oestrous cycle allowed recipient ewes to accept and maintain older conceptuses successfully after embryo transfer (Moore, 1975; Lawson \& Cahill, 1983; Vincent et al., 1985). These data suggest that progesterone administration to recipients during the early oestrous cycle results in specific changes within the uterine environment which accommodate conceptuses at a more advanced stage. The specific changes or release of specific factor(s) which mediate the development of the conceptus are unknown.

Effects of progesterone administration on conceptus development, survival and uterine endometrial secretion during early pregnancy in the cow are unknown. The objective of the present study was to determine the effects on uterine secretion and conceptus development after exogenous progesterone treatment during early pregnancy.

\section{Materials and Methods}

Animals. Fifty-one cyclic beef cows, maintained on pasture and fed prairie hay ad libitum, were observed twice daily (a.m. and p.m.) for oestrous behaviour (oestrus $=$ Day 0 ). Upon detection of oestrus, cows were mated with fertile bulls.

Cows were randomly assigned to receive one of the following treatments: (a) intramuscular injection ( $2 \mathrm{ml})$ of vehicle (sesame oil) on Days 1, 2, 3 and 4 of pregnancy (control); (b) intramuscular injection (100 mg) of progesterone (Henry Schein, Inc., Port Washington, NY, U.S.A.) on Days I, 2, 3 and 4 of pregnancy. The first injection (Day 1) was administered $36 \mathrm{~h}$ after the initial observation of oestrus and the remaining injections were administered at 24-h intervals thereafter. Cows within treatment groups were than randomly assigned to be slaughtered on Days 5 or 14, or palpated for pregnancy per rectum on Day 40.

Blood samples $(10 \mathrm{ml})$ were collected daily by jugular venepuncture until slaughter. Animals that were allowed to continue pregnancy to Day $\mathbf{4 0}$ were sampled to Day 5. Samples were placed on ice, transported to the laboratory and centrifuged at $2400 \mathrm{~g}$ for $15 \mathrm{~min}$ at $4^{\circ} \mathrm{C}$. Plasma was decanted and stored at $-15^{\circ} \mathrm{C}$ until analysed for progesterone concentration.

Uteri from cows slaughtered on Days 5 and 14 were recovered within $5 \mathrm{~min}$ after exsanguination, placed in a sterile beaker on ice and transported to the laboratory for processing in a sterile, laminar flow hood. The broad ligament and ovaries were trimmed free of the uterus. Each uterine horn was clamped near the bifurcation and flushed separately with sterile $0.9 \%(\mathrm{w} / \mathrm{v})$ saline $(20 \mathrm{ml})$ to recover uterine luminal contents. Uterine flushings were immediately examined for embryos (Day 5) or conceptus tissue (Day 14). Uterine flushings were centrifuged at $12000 \mathrm{~g}$ for $20 \mathrm{~min}$ at $4^{\circ} \mathrm{C}$. The supernatant was decanted and stored at $-15^{\circ} \mathrm{C}$ until analysed for protein (quantitative and qualitative) content. After flushing, the uterine horns were opened along the antimesometrial border and endometrial explants were obtained from the horns contralateral and ipsilateral to the CL for in-vitro culture.

In-vitro culture. Intercaruncular endometrium from uterine horns ipsilateral and contralateral to the CL was dissected from the underlying myometrium and immediately placed in sterile modified Eagle's minimum essential media (MEM) as described by Basha et al. (1979). Tissue was cut into $2-3 \mathrm{~mm}^{2}$ explants using sterile scalpel blades. Approximately $500 \mathrm{mg}$ wet tissue were cultured in $15 \mathrm{ml}$ sterile MEM containing one-tenth of the normal concentration of leucine. Tritium-labelled leucine (L- $\left[4,5-{ }^{3} \mathrm{H}\right]$ leucine; sp. act. $58.4 \mathrm{Ci} / \mathrm{mmol}$ : New England Nuclear, Boston, MA, U.S.A.) was added $(100 \mu \mathrm{Ci})$ to each culture dish as a tracer for de-novo protein synthesis. Day 14 conceptuses ( $n=5 ; 2$ control and 3 progesterone-treated) recovered from uterine flushings were cultured in $3 \mathrm{ml}$ MEM with $25 \mu \mathrm{Ci}\left[{ }^{3} \mathrm{H}\right] \mathrm{leucine}$.

Tissue cultures were rocked slowly $(4.5 \mathrm{cycles} / \mathrm{min})$ in a controlled atmospheric chamber (Bellco Biological Glassware, Vineland, NJ, U.S.A.) which was purged with a gas mixture of $45 \% \mathrm{O}_{2} / 50 \% \mathrm{~N}_{2} / 5 \% \mathrm{CO}_{2}$ and maintained at $37^{\circ} \mathrm{C}$ as described previously by Basha et al. (1979). Following a 24-h culture period, culture medium from endometrial and conceptus tissue was decanted, centrifuged at $12000 \mathrm{~g}$ for $20 \mathrm{~min}$ at $4^{\circ} \mathrm{C}$ and stored at $-87^{\circ} \mathrm{C}$ until analysis for polypeptide production.

Two-dimensional polyacrylamide gel electrophoresis (2D-PAGE). Uterine flushings and culture media from conceptus and endometrial explants were dialysed (Spec/por 3, $M_{\mathrm{r}}$ cutoff $=3500$; Spectrum Medical Industries, Inc., Los Angeles, CA, U.S.A.) against several volume changes of $10 \mathrm{~mm}$-Tris- $\mathrm{HCl}$ buffer $(\mathrm{pH} 8.2)$ followed by one volume change of double-distilled water. Following dialysis, an aliquant $(100 \mu \mathrm{l})$ of medium from each culture was used to determine the total d.p.m. of $\left[{ }^{3} \mathrm{H}\right]$ leucine retained as a non-dialysable product. Uterine flushings and media from individual conceptus and endometrial cultures were lyophilized and then reconstituted in $5 \mathrm{~mm}-\mathrm{K}_{2} \mathrm{CO}_{3}$ containing $9.4 \mathrm{M}$-urea, $2 \%(\mathrm{v} / \mathrm{v})$ Nonidet P-40 and $0.5 \%(\mathrm{w} / \mathrm{v})$ dithiothreitol. Two-dimensional polyacrylamide gel electrophoresis of the acidic and basic polypeptides present in uterine flushings and culture media was performed as 
described by Basha et al. (1980). Protein $(300 \mu \mathrm{g})$ from each uterine flushing was applied to gels for 2D-PAGE analysis. Gels of uterine flushings were silver stained according to the procedure described by Wray et al. (1981).

About 150000 d.p.m. from individual endometrial explant cultures and the 3-ml dialysate $\left(480-600 \times 10^{3}\right.$ d.p.m.) from each conceptus culture were applied to gels. After electrophoresis, gels were stained with Coomassie Brilliant Blue R-250; impregnated with sodium salicylate (Chamberlain, 1979), dried and fluorographs were prepared using Kodak XAR X-ray film (Eastman Kodak Co., Rochester, NY, U.S.A.). Fluorographs were developed after an 11-week exposure period at $-87^{\circ} \mathrm{C}$.

Protein analysis. Protein concentration in uterine flushings was measured by the colorimetric method as described by Lowry et al. (1951) using bovine serum albumin as the standard.

Peripheral plasma progesterone analysis. Plasma samples were analysed for progesterone concentration by radioimmunoassay as previously described and validated by Lusby et al. (1981). Recovery of labelled progesterone tracer after hexane extraction was $89 \%$. The minimum sensitivity of the assay was $25 \mathrm{pg} / \mathrm{ml}$. Intra- and interassay coefficients of variation were $7 \cdot 7 \%$ and $12 \cdot 2 \%$, respectively.

Statistical analysis. Data were analysed by least square analysis of variance using the General Linear Models procedures of the Statistical Analysis System (Spector et al., 1985). The statistical model for analyses of concentration of progesterone in plasma included effects of treatment (control and progesterone treatment), cow within treatment, day and treatment by day interactions. Effect of treatment was tested with cow within treatment as the error. Conceptus length on Day 14 in the control and progesterone-treated groups was analysed by Bartlett's test for homogeneity of variance (Steel \& Torrie, 1980). Variances of treatment groups were different $(P<0.05)$. Therefore, conceptus length was analysed for differences between treatments by Student's $t$ test for unequal variances. The statistical model for uterine protein content and incorporation of $\left[{ }^{3} \mathrm{H}\right] l$ leucine by endometrial explants included effects of treatment, day and treatment by day interaction.

\section{Results}

A treatment by day interaction $(P<0.001)$ was detected for plasma progesterone concentration. Administration of exogenous progesterone on Days 1, 2, 3 and 4 of pregnancy increased $(P<0.001)$ peripheral plasma progesterone concentrations on Days $2-5$ of pregnancy $(3.40 \pm 0.09 \mathrm{ng} / \mathrm{ml})$ compared to control $(1.22 \pm 0.09 \mathrm{ng} / \mathrm{ml})$ cows (Fig. 1).

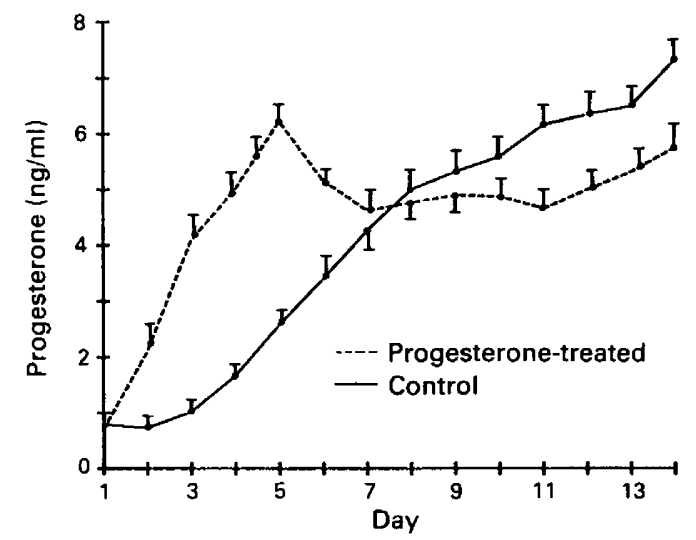

Fig. 1. Peripheral plasma progesterone concentrations during early pregnancy of control and progesterone-treated cows.

Recovery of Day-5 embryos was low for both control (3/7) and progesterone-treated (1/7) cows. Embryos recovered from control cows were 8 to 16 cells, while one 32-cell embryo and 2 empty zonae pellucidae were recovered from progesterone-treated cows (Fig. 2a,b). Although no embryos were found in flushings containing empty zonae pellucidae, the zonae were ruptured and embedded with accessory spermatozoa (Fig. 2b).

Conceptuses recovered from Day-14 uteri of progesterone-treated (7/10) cows were larger $(P<0 \cdot 10)$ than (Fig. 2d) conceptuses recovered (6/7) from controls (Fig. 2c). Day-14 conceptuses from progesterone-treated cows averaged $37.3 \pm 14.9 \mathrm{~mm}$ in length compared to $3.8 \pm 1.9 \mathrm{~mm}$ for 

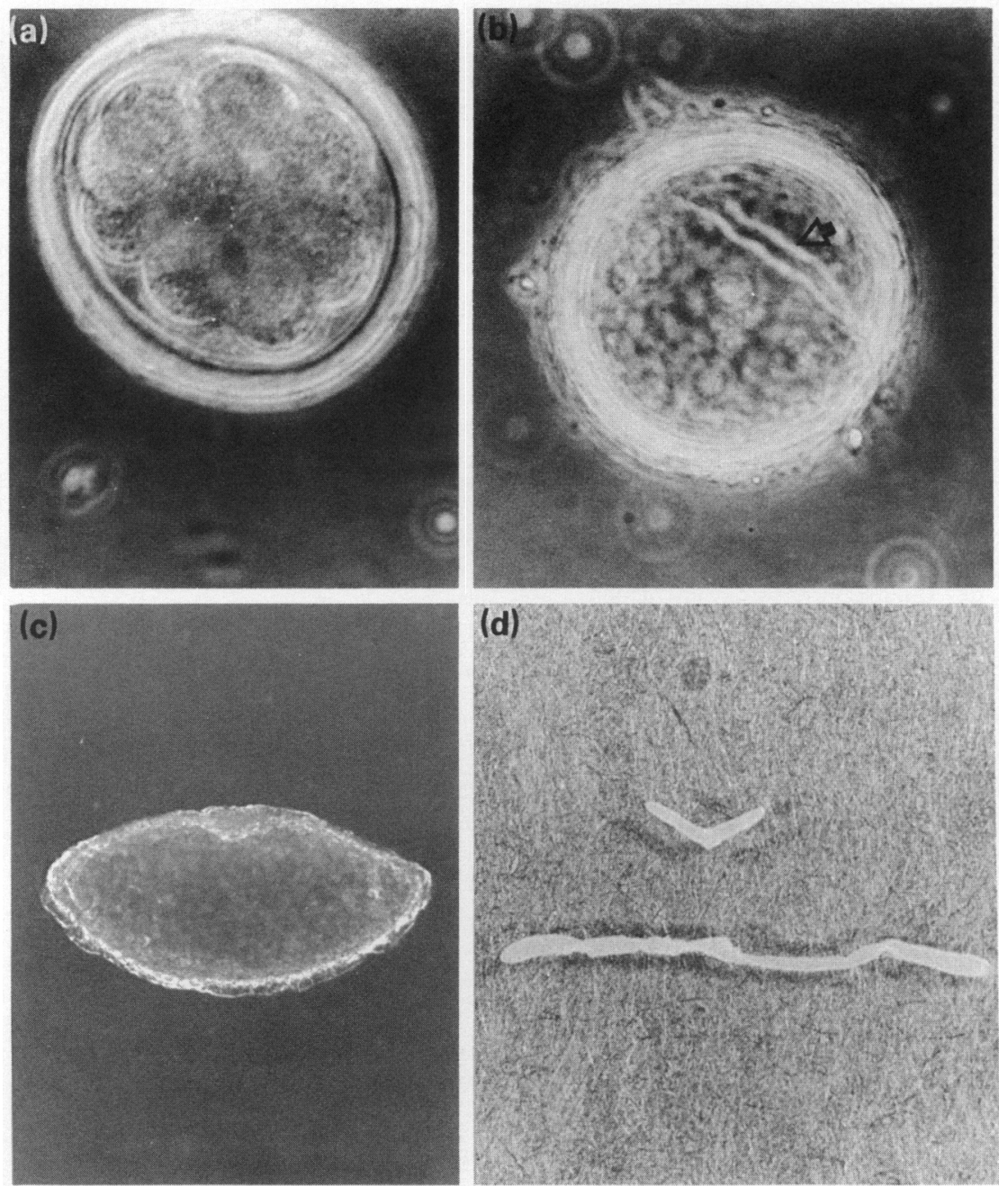

Fig. 2. Representative embryos which were recovered in uterine flushings from control and progesterone-treated cows on Days 5 and 14 of pregnancy. (a) Embryo of 16 cells from a control cow flushed on Day 5. (b) Empty zona pellucida recovered from a progesterone-treated cow on Day 5. Note the slit (arrow) and the presence of accessory spermatozoa in the zona. (c) Conceptus $(1.7 \mathrm{~mm})$ from a control cow on Day 14. (d) Conceptuses from (upper) control cow $(13 \mathrm{~mm})$ and (lower) progesterone-treated cow $(47 \mathrm{~mm})$ recovered on Day 14.

conceptuses from control cows. Conceptus length ranged from 1 to $13 \mathrm{~mm}$ in control compared with 3 to $119 \mathrm{~mm}$ for progesterone-treated cows. Progesterone treatment not only increased morphological development of Day-14 conceptuses but also advanced biosynthetic activity as indicated by fluorographs from conceptus cultures (Fig. 3). The complex of polypeptides $\left(M_{\mathrm{r}} 22-26 \times 10^{3}\right.$, pI 5.8-6.4) forming the bovine trophoblast protein complex (bTP-1), proposed to be involved with the maintenance of early CL function (Thatcher et al., 1986), was prominent in conceptus cultures from progesterone-treated cows, but absent from control conceptus cultures (Fig. 3). Progesterone administration did not appear to have adverse effects upon maintenance of pregnancy as pregnancy rates determined through rectal palpation on Day 40 were similar in control (6/8) and 
progesterone-treated $(7 / 11)$ cows. One cow which had a prolapsed cervix was excluded from the study.

Analysis of the uterine environment on Days 5 and 14 indicated that progesterone administration altered secretory activity of uterine endometrium. Total protein content in uterine flushings on Day 14 was greater $(P<0.05)$ in progesterone-treated cows $(15.2 \pm 2.0 \mathrm{mg})$ compared with controls $(8 \cdot 26 \pm 2 \cdot 4 \mathrm{mg})$. However, a day effect was not detected.

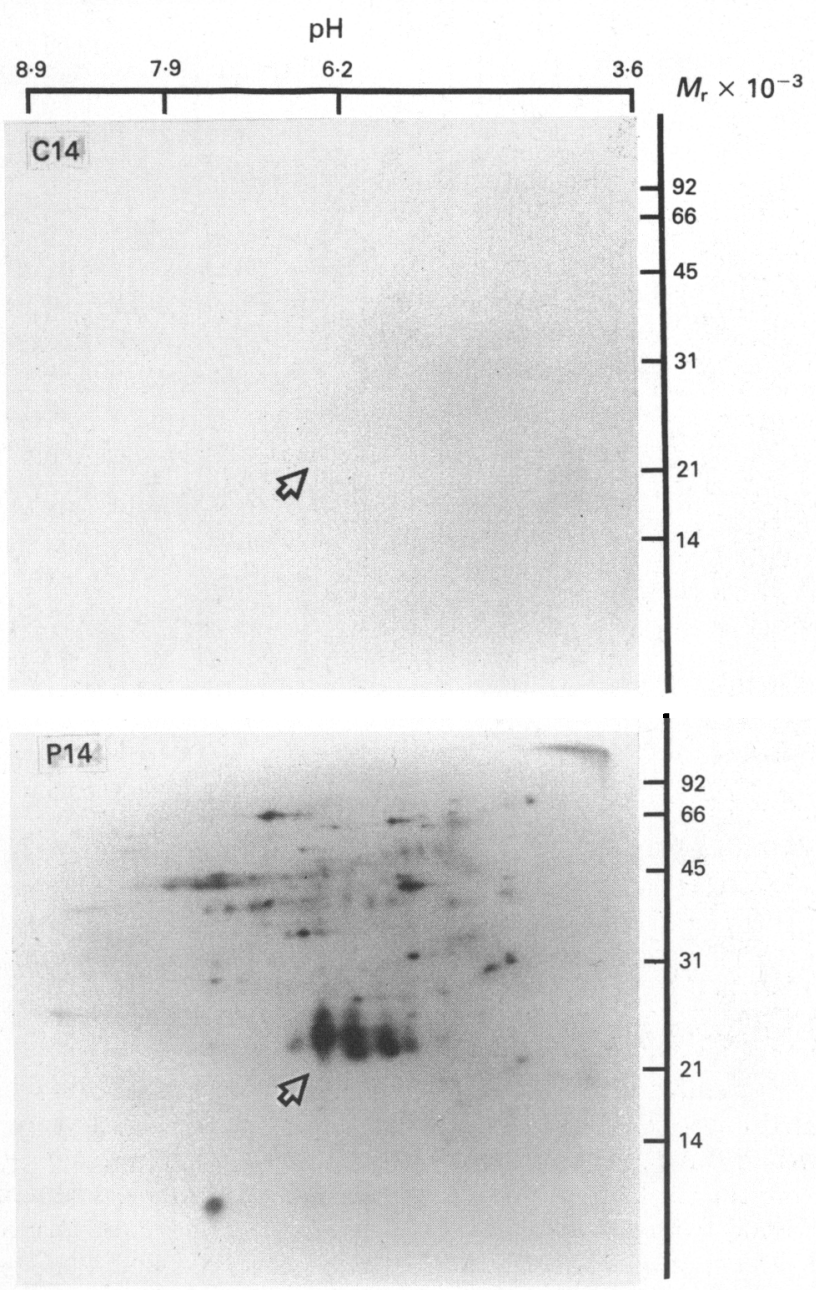

Fig. 3. Fluorographs representative of 2D-PAGE gels of acidic polypeptides in dialysed bovine conceptus culture media from Day 14 control (C14) and progesterone-treated (P14) cows. Arrow denotes position of the bTP-1 complex. Note absence of bTP-1 in culture medium of the control conceptus.

Two-dimensional polyacrylamide gel electrophoresis of uterine flushings revealed several acidic polypeptides which were not present in bovine plasma (Fig. 4). No obvious differences were observed between control and progesterone-treated cows on Days 5 or 14 of pregnancy. A day effect was noted as a group of polypeptides with an $M_{\mathrm{r}}$ of $26-30 \times 10^{3}$, pI 4.2-5.5, intensified on Day 5 compared to 14 (Fig. 4, solid arrow). Day-14 uterine flushings (Fig. 4) contained two groups 

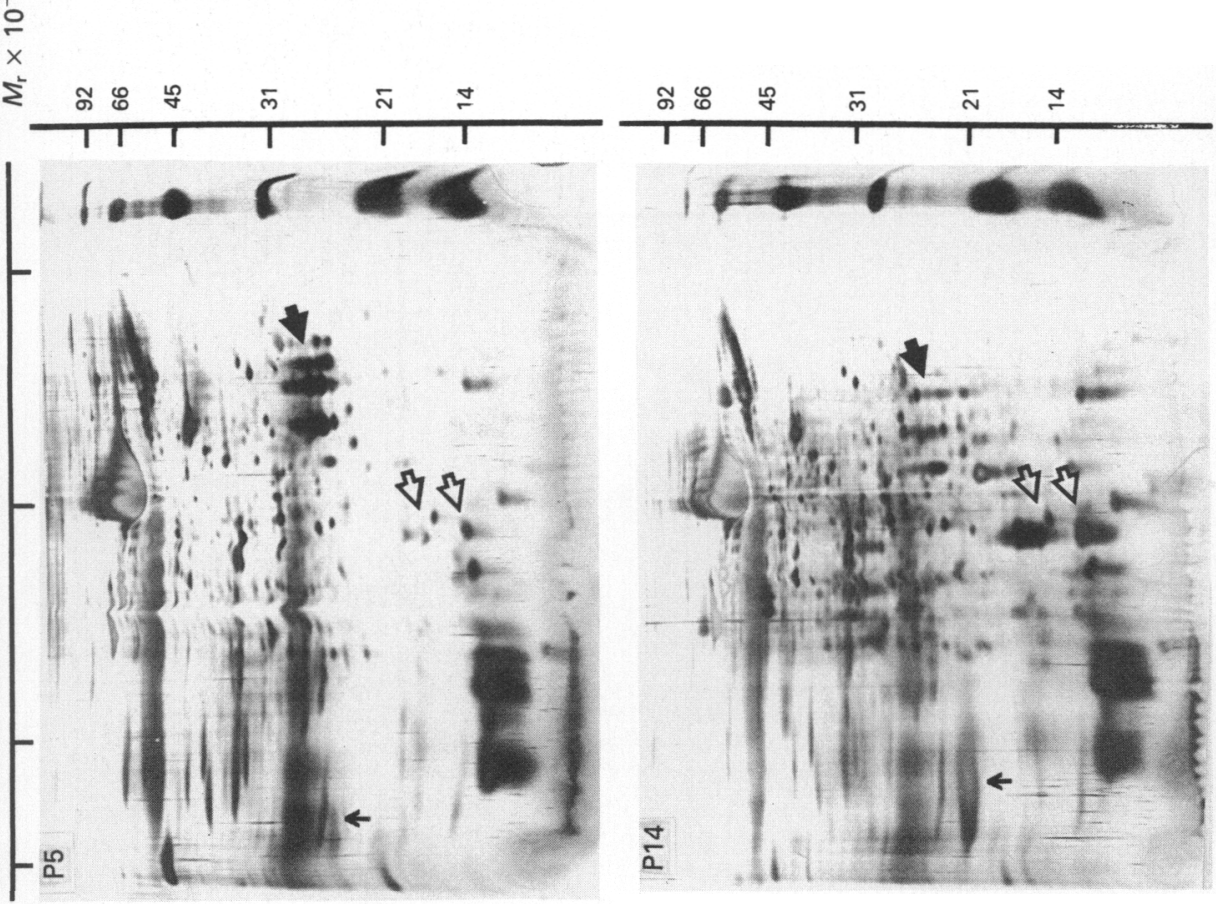

I
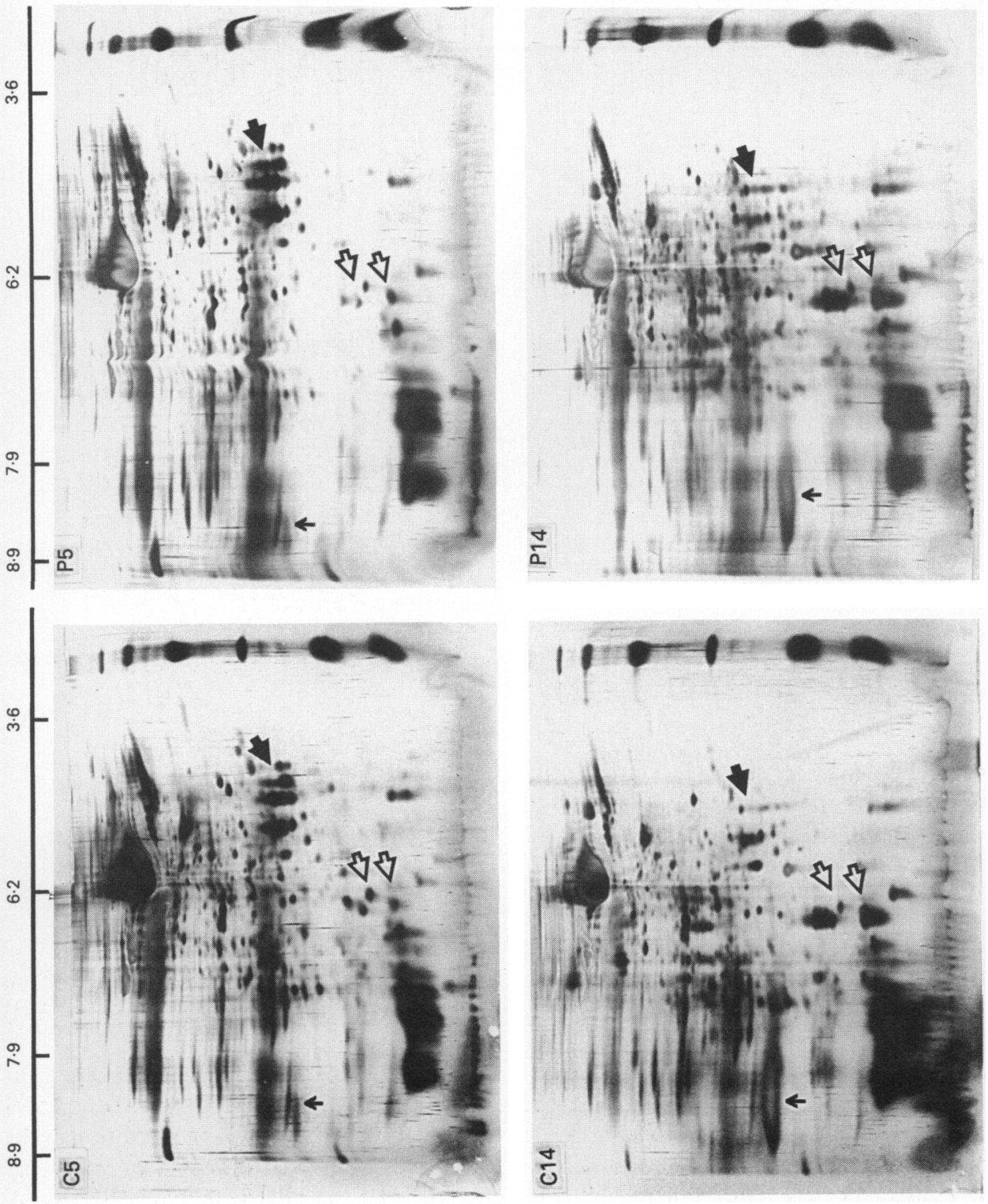

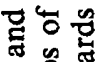

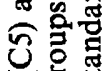

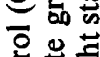
웅영

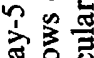
柁 हरำ 管 उ。 界䒕. 흥 品实 䟢 空 类 世 울 造 동 क 등 昰卷 등잉

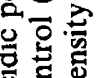
证 पे 品穿严 可焉 О․ㅛ ते व

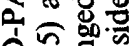
ति उ $\overline{8}$. G P 3 就 궁을 + 要 봉영 


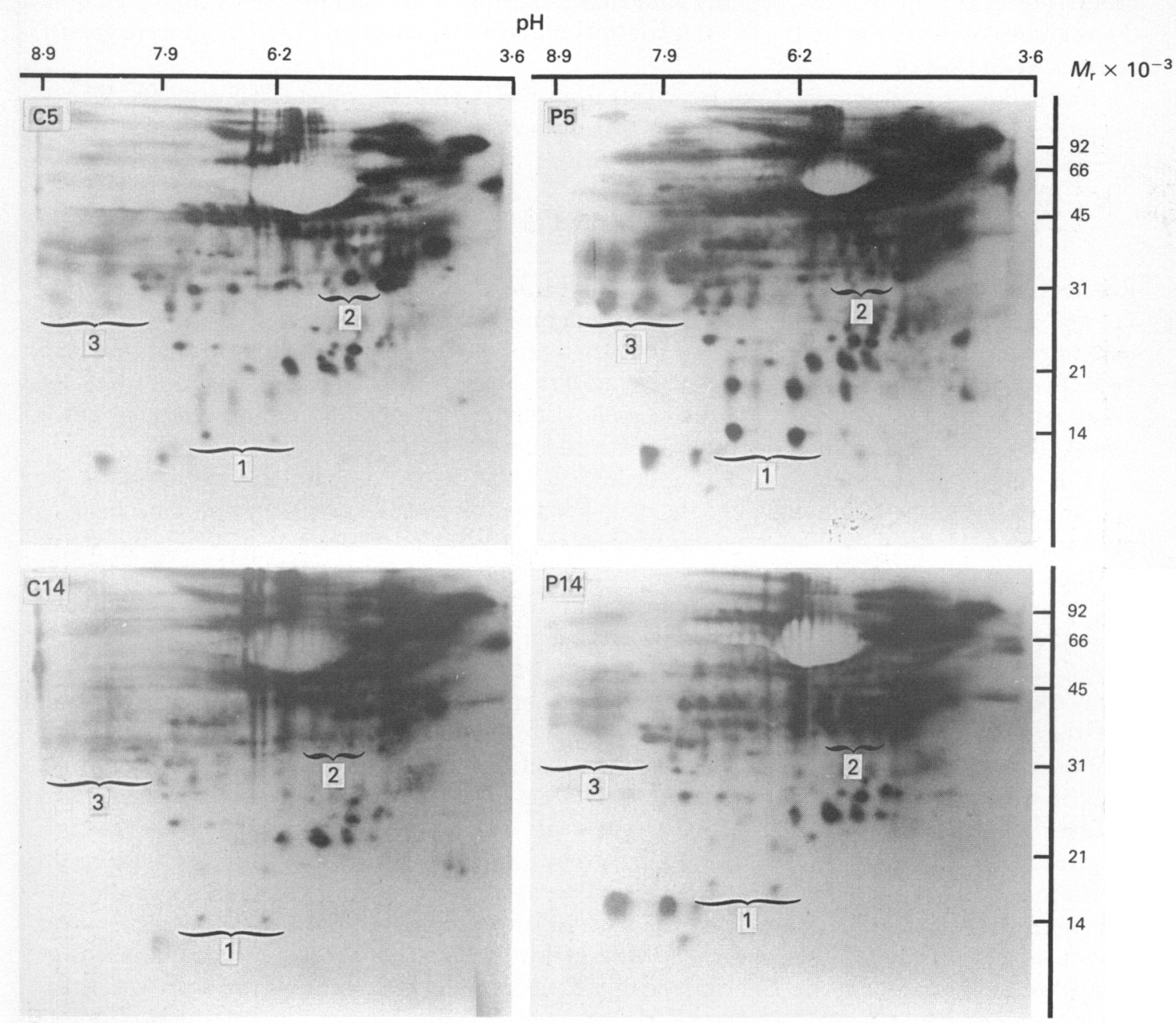

Fig. 5. Fluorographs of 2D-PAGE gels of acidic polypeptides in dialysed endometrial culture medium from the ipsilateral uterine horn of Day-5 control (C5) and progesterone-treated (P5), and Day-14 control (C14) and progesterone-treated (P14) cows. Three $M_{\mathrm{r}}\left(\times 10^{3}\right) / \mathrm{pI}$ groups presented in the fluorographs include: $1, \cong 16-20 / 6 \cdot 3-7 \cdot 0 ; 2, \cong 40 / 5 \cdot 7-6 \cdot 4$; and 3 , $\cong 31-41 / 7 \cdot 9-8 \cdot 9$.

of polypeptides $\left(M_{\mathrm{r}} 21 \times 10^{3}\right.$, pI $6 \cdot 3$, and $M_{\mathrm{r}} 14.4 \times 10^{3}$, pl 6.3), represented by open arrows, which increased in intensity compared to Day 5 . A basic (pI 7.9-8.9) polypeptide $\left(M_{\mathrm{r}} 22-26 \times 10^{3}\right)$ was also increased on Day 14 (small arrow).

Overall incorporation of $\left[{ }^{3} \mathrm{H}\right]$ leucine per $\mathrm{mg}$ wet tissue weight was $3469 \pm 285$ d.p.m. for treatment and day. Evaluation of fluorographs from Day-5 and -14 intercaruncular endometrial explant cultures of the ipsilateral horn from progesterone-treated cows revealed an alteration in the intensity of two separate groups of polypeptides compared to fluorographs from control cows (Fig. 5). Group 1 consisted of 4 low molecular weight $\left(16-20 \times 10^{3}\right)$ polypeptides with a pI of $\sim 6 \cdot 3-7 \cdot 0$. These polypeptides had greater intensity on fluorographs from Day-5 progesterone-treated cows compared with fluorographs from Day-5 control and Day-14 control and progesterone-treated cows. Group 2 consisted of polypeptides with an $M_{\mathrm{r}}$ of $40 \times 10^{3}$ and pI 5.7-6.4 which were intensified in fluorographs from Day-14 progesterone-treated compared with control cultures. A third 
group (Fig. 5, Group 3) of polypeptides with an $M_{\mathrm{r}}$ of 31-40 $\times 10^{3}$ and $\mathrm{pI} 7.9-8.9$ were present in fluorographs of progesterone-treated and control endometrial cultures on Day 5 , but were greatly attenuated on Day 14.

Evaluation of fluorographs from basic gels from Day-5 and -14 endometrial explants did not indicate any clear difference in polypeptide synthesis between treatment groups.

\section{Discussion}

Results from the present study indicate that administration of exogenous progesterone on Days 1, 2,3 and 4 of pregnancy increases peripheral plasma progesterone concentration on Days 2-5 compared to control cows. A similar increase in plasma progesterone concentration was not observed until Day 5 or 6 in control cows. These results suggest that increased concentrations of progesterone during the first 5 days of pregnancy stimulate changes in uterine secretions which directly or indirectly stimulate conceptus growth and development.

The 4-day progesterone treatment appeared to alter the functional state of the uterus as determined by uterine secretions. Changes in uterine development are consistent with shortening of the oestrous cycle by 4 days after similar progesterone treatment (Woody et al., 1967; Woody \& Ginther, 1968; Harms \& Malven, 1969; Ginther, 1970; Battista et al., 1984; Garrett et al., 1987). It has been suggested that the decreased interoestrous interval after treatment with exogenous progesterone is mediated through earlier maturation of the uterus as indicated by an earlier release of PGF-2 $\alpha$ from the uterine endometrium (Garrett et al., 1987). The alteration in secretory activity of the endometrium in vitro indicates that exogenous progesterone stimulated uterine endometrial secretory function compared to controls.

Previous studies in the ewe have demonstrated that administration of exogenous progesterone early in pregnancy allows older embryos to be transferred and maintained in 'younger' uteri (Moore, 1975; Lawson \& Cahill, 1983; Vincent et al., 1985). Day-8 cattle embryos can establish pregnancy when transferred to Day-5 recipient cows treated with progesterone compared with asynchronous controls (T. C. Fox \& R. D. Geisert, unpublished). These results suggest that progesterone stimulates uterine endometrial secretions which are favourable for development and growth of older embryos. Bartol et al. (1981) indicated that endometrial polypeptides change throughout the oestrous cycle. The increase in protein in the uterine flushings from progesteronetreated cows on Day 14 could be related to the length of progesterone exposure. Bartol et al. (1981) indicated that protein accumulation within the uterine lumen is related to length of progesterone stimulation. Analysis of uterine flushings in our study revealed that selective qualitative changes occurred in polypeptide release from Days 5 to 14 of pregnancy. Polypeptides which incorporated $\left[{ }^{3} \mathrm{H}\right] \mathrm{leucine}$ after endometrial explant culture were similar to those of previous reports (Bartol et al., 1985; Geisert et al., 1988). The present study indicates that exposure to progesterone early in pregnancy results a change in the synthesis and secretion of several polypeptides from the uterine endometrium on Day 5 . The function of these polypeptides is presently not known. However, it is possible that they are involved with conceptus development.

Embryos of 8-16 cells recovered at Day 5 of pregnancy in control cows were comparable in development to those reported by others (Chang, 1952; Flechon \& Renard, 1978). Low embryo recovery does not allow us to compare treatment groups. However, the presence of empty zonae pellucidae in which a slit on the surface suggesting hatching may have occurred in the progesteronetreated cows is of interest. Blastocyst hatching normally occurs on Days 9-11 of pregnancy (Flechon \& Renard, 1978; Shea, 1981). Recovery of empty zonae pellucidae has been reported previously in cattle (Maurer \& Chenault, 1983). Although it is possible that hatching may have occurred in these animals, the empty zonae could be remnants of degenerated embryos.

It is evident that conceptuses from progesterone-treated cows can survive and appear to be more morphologically developed because conceptus length on Day 14 was greater than that for 
embryos recovered from control cows. Greater variation in conceptus development was observed in progesterone-treated cows. This variation could be related to individual uterine sensitivity to progesterone, as observed in cycle length of progesterone-treated non-pregnant cows (Garrett $e t$ al., 1987). However, similar variation normally occurs during conceptus development on Days 15-17 when rapid expansion of the trophoblast membrane is initiated (Betteridge et al., 1980). Day-14 conceptuses from progesterone-treated cows synthesized and released polypeptides, including bTP-1, which are associated with pregnancy recognition in the cow (Knickerbocker et al., 1986). Since luteal regression occurs on Day 16 in non-pregnant progesterone-treated cows (Garrett et al., 1987), early synthesis and release of bTP-1 would be vital since the pregnancy recognition signal from the conceptus is needed much earlier to prevent luteal regression. The similar pregnancy rates between progesterone-treated and control cows on Day 40 of gestation provide further evidence of the viability of the developmentally advanced conceptuses.

Exogenous progesterone administration stimulates a marked development in conceptuses of cattle but not in those of pigs (R. D. Geisert, unpublished data). The cow, unlike the sow, exhibits a period of low concentrations of peripheral plasma progesterone during the first 5 days of pregnancy. Peripheral plasma progesterone concentrations in the cow gradually increase from $<1 \mathrm{ng} / \mathrm{ml}$ during oestrus to $\sim 2 \mathrm{ng} / \mathrm{ml}$ on Day 5 . In the sow, peripheral plasma progesterone concentrations rise more sharply after oestrus (Guthrie et al., 1972). The uterine environment in the sow may already be under the influence of progesterone during the first few days of pregnancy and so dramatic changes in embryo development due to exogenous progesterone administration would not be seen.

Reports for other species have indicated that ovarian steroids can influence uterine secretions for activation of embryonic growth and development (see Renfree \& Calaby, 1981). For example, in the macropodid marsupials, embryos undergo a period of diapause before continuing development. The stimulus for activation of the embryo is related to an increase in progesterone production from the corpus luteum (see review by Tyndale-Biscoe \& Hinds, 1981).

The results of the present study indicate that the conceptus of cattle may not develop at its maximum potential during the first 5 days of pregnancy. Administration of exogenous progesterone on Days 1, 2, 3 and 4 of pregnancy may therefore stimulate an earlier activation of the conceptus by altering the release of uterine secretions and/or selective transport of serum proteins necessary for conceptus development. These results suggest that maternal progesterone may regulate early conceptus growth and development in cattle.

Journal Article No. 5358 of Agricultural Experiment Station, Oklahoma State University, Stillwater. We thank L. Gries for technical assistance; and Tammy Cozzens for secretarial assistance.

\section{References}

Bartol, F.F., Thatcher, W.W., Lewis, G.S., Bliss, E.L., Drost, M. \& Bazer, F.W. (1981) Effect of estradiol$17 \beta$ on PGF and total protein content in bovine uterine flushings and peripheral plasma concentration of 13,14-dihydro-15-keto-PGF ${ }_{2 \alpha}$. Theriogenology 15, 345-358.

Bartol, F.F., Roberts, R.M., Bazer, F.W. \& Thatcher, W.W. (1985) Characterization of proteins produced in vitro by bovine endometrial explants. Biol. Reprod. 33, 745-759.

Basha, S.M., Bazer, F.W. \& Roberts, R.M. (1979) The secretion of a uterine specific, purple phosphatase by cultured explants of porcine endometrium. Dependency upon the state of pregnancy of the donor animal. Biol. Reprod. 20, 431-441.
Basha, S.M., Bazer, F.W., Geisert, R.D. \& Roberts, R.M. (1980) Progesterone-induced uterine secretions in pigs. Recovery from pseudopregnant and unilaterally pregnant gilts. J. Anim. Sci. 50, 113-123.

Battista, P.J., Rexroad, C.E., Jr \& Williams, W.F. (1984) Effects of progesterone administered to dairy heifers on sensitivity of corpora lutea to $\mathrm{PGF}_{2 a}$ and on plasma LH concentration. Theriogenology 22 47-58.

Betteridge, K.J., Eaglesome, M.D., Randall, G.C.B. \& Mitchell, D. (1980) Collection, description and transfer of embryos from cattle 10-16 days after oestrus. J. Reprod. Fert. 59, 205-216.

Chamberlain, J.P. (1979) Fluorographic detection of radioactivity in polyacrylamide gels with the water 
soluble fluor, sodium salicylate. Analyt. Biochem. 98, 132-135.

Chang, M.C. (1952) Development of bovine blastocyst with a note on implantation. Anat. Rec. 113, 143-161.

Flechon, J.E. \& Renard, J.P. (1978) A scanning electron microscope study of the hatching of bovine blastocysts in vitro. J. Reprod. Fert. 53, 9-12.

Garrett, J.E., Geisert, R.D., Morgan, G.L., Wettemann, R.P., Zavy, M.T., Gries, L.K. \& Buchanan, D.S. (1987) Effect of exogenous progesterone on cycle length, embryonic development and maintenance of pregnancy in the bovine. J. Anim. Sci. 65 (Suppl. 1), 418, Abstr.

Geisert, R.D., Zavy, M.T., Biggers, B.G., Garrett, J. E. \& Wettemann, R.P. (1988) Characterization of the uterine environment during early conceptus expansion in the bovine. Anim. Reprod. Sci. 16, 11-25.

Ginther, O.J. (1970) Effect of progesterone on length of estrous cycle in cattle. Am. J. vet. Res. 31, 493-496.

Guthrie, H.D., Henricks, D.M. \& Handlin, D.L. (1972) Plasma estrogen, progesterone and luteinizing hormone prior to estrus and during early pregnancy in pigs. Endocrinology 91, 675-679.

Harms, P.G. \& Malven, P.V. (1969) Modification of bovine luteal function by exogenous oxytocin and progesterone. J. Anim. Sci. 29, 25-29.

Knickerbocker, J.J., Thatcher, W.W., Bazer, F.W., Drost, M., Barron, D.H., Fincher, K.B. \& Roberts, R.M. (1986) Proteins secreted by Day 16-18 bovine conceptuses extend corpus luteum function in cows. J. Reprod. Fert. 77, 381-391.

Lawson, R.A.S. \& Cahill, L.P. (1983) Modification of the embryo-maternal relationship in ewes by progesterone treatment early in the oestrous cycle. J. Reprod. Fert. 67, 473-475.

Lowry, O.H., Rosebrough, N.J., Farr, A.L. \& Randall, R.J. (1951) Protein measurement with the folin phenol reagent. J. biol. Chem. 193, 265-275.

Lusby, K.S., Wettemann, R.P. \& Turman, E.J. (1981) Effects of early weaning calves from first-calf heifers on calf and heifer performance. J. Anim. Sci. 53, 1193-1197.

Maurer, R.R. \& Chenault, J.R. (1983) Fertilization failure and embryonic mortality in parous and nonparous beef cattle. J. Anim. Sci. 56, 1186-1189.
Moore, N.W. (1975) Progesterone requirements for the maintenance of pregnancy in the ovariectomized ewe. J. Reprod. Fert. 43, 386-387.

Ottobre, J.S., Lewis, G.S., Thayne, W.V. \& Innskeep, E.K. (1980) Mechanism by which progesterone shortens the estrous cycle of the ewe. Biol. Reprod. 23, 1046-1053.

Renfree, M.B. \& Calaby, J.H. (1981) Background to delayed implantation and embryonic diapause. $J$. Reprod. Fert., Suppl. 29, 1-9.

Rowson, L.E.A., Moor, R.M. \& Lawson, R.A.S. (1969) Fertility following egg transfer in the cow: effect of method, medium any synchronization of oestrus. $J$. Reprod. Fert. 18, 517-523.

Shea, B.F. (1981) Evaluating the bovine embryo. Theriogenology 15, 31-35.

Spector, P.C., Goodnight, J.H., Sall, J.P. \& Sarle, W.S. (1985) The GLM procedure. In SAS User's Guide: Statistics, Version 5 Edition, pp.433-507. SAS Institute, Cary, N.C.

Steel, R.D.G. \& Torrie, J.H. (1980) Homogeneity of variance. In Principles and Procedures of Statistics: A Biometrical Approach, 2nd edn, pp.471-472. McGraw-Hill Book Co., New York.

Thatcher, W.W., Bazer, F.W., Sharp, D.C. \& Roberts, R.M. (1986) Interrelationships between uterus and conceptus to maintain corpus luteum function in early pregnancy: sheep, cattle, pigs and horses. $J$. Anim. Sci. 62 (Suppl. 2), 25-46.

Tyndale-Biscoe, C.H. \& Hinds, L. (1981) Hormonal control of the corpus luteum and embryonic diapause in macropodid marsupials. J. Reprod. Fert., Suppl. 29, $111-117$.

Vincent, D.L., Meredith, S. \& Inskeep, E.K. (1985) Effects of progesterone and age of blastocyst on utero-ovarian venous $\mathrm{PGE}_{2}$. J. Anim. Sci. 61 (Suppl. I), 400, Abstr.

Woody, C.O. \& Ginther, O.J. (1968) Effect of exogenous progesterone on corpora lutea in unilaterally hysterectomized heifers. J. Anim. Sci. 27, 1387-1390.

Woody, C.O., First, N.L. \& Pope, A.L. (1967) Effect of exogenous progesterone on estrous cycle length. $J$. Anim. Sci. 26, 139-141.

Wray, W., Boulikas, T., Wray, V.P. \& Hancock, R. (1981) Silver staining of proteins in polyacrylamide gels. Analyt. Biochem. 118, 197-203.

Received 5 February 1988 